\title{
„DYM ULECIAE, A OTULONA ŚNIEGIEM RÓWNINA TORIBE ODDAJE NASTRÓJ ŻURAWIEGO GAJU". O BUDDYJSKIEJ IDEI PRZEMIJANIA I WĄTKACH NEKROPOLICZNYCH W JAPOŃSKIEJ LITERATURZE WCZESNEGO ŚREDNIOWIECZA
}

\author{
ADAM BEDNARCZYK ${ }^{1}$ \\ (Uniwersytet im. Mikołaja Kopernika w Toruniu)
}

Słowa kluczowe: japońska literatura dworska - okres Heian - przemijanie - buddyzm Toribe - nekropolia

Key words: Japanese courtly literature - Heian period - evanescense - Buddhism -

Toribe - necropolis

\begin{abstract}
Abstrakt: Adam Bednarczyk. „DYM ULECIAE, A OTULONA ŚNIEGIEM RÓWNINA TORIBE ODDAJE NASTRÓJ ŻURAWIEGO GAJU". O BUDDYJSKIEJ IDEI PRZEMIJANIA I WĄTKACH NEKROPOLICZNYCH W JAPOŃSKIEJ LITERATURZE WCZESNEGO ŚREDNIOWIECZA. PORÓWNANIA 18, 2016. T. XVIII. S. 91-114. ISSN 1733-165X. Wątki nekropoliczne w japońskiej literaturze wczesnego średniowiecza są tematyką do tej pory mało badaną i opisywaną. Pomimo licznych deskrypcji śmierci różnych osób, szczegóły na temat miejsc grzebania i kremacji, a także towarzyszących im ceremoniom, pozostają w dalszym ciągu słabo omówione. Niniejszy artykuł jest próbą uchwycenia znaczenia i metaforyki Toribe, jako jednego z nielicznych miejsc nekropolicznych, które stało się wątkiem lub motywem utworów literackich począwszy od okresu Heian (794-1192). W tym celu autor skupił się z jednej strony na stricte toponimicznym ujęciu Toribe, umożliwiającym interpretację wybranych fragmentów literackich pod kątem rzeczywistego opisu tejże nekropolii. Natomiast szczegółowe zbadanie motywu Toribe, jako toposu, miało przybliżyć kilka możliwych ścieżek jego interpretacji, od rozbudowanej metafory, aż po jego funkcję zdobniczą.
\end{abstract}

${ }^{1}$ E-mail Address: a_bed@umk.pl 


\begin{abstract}
Adam Bednarczyk. "THE SMOKE ENDED, AND TORIBENO IN ITS SNOWY MANTLE SEEMS TO A GRIEVING HEART LIKE THE WHITENED TREES OF CRANE GROVE". ON THE BUDDHIST CONCEPT OF VANITY AND NECROPOLISTIC THREADS IN JAPANESE LITERATURE OF THE EARLY MEDIEVAL PERIOD. COMPARISONS 18, 2016. Vol. XVIII. P. 91-114. ISSN 1733-165X. The necropolistic threads in Japanese literature of the early medieval times have been scarcely discussed material. Although there are extant numerous accounts on someone's dead, details concerning places of burial or cremation and descriptions of accompanying ceremonies are almost unknown. The present paper is an attempt to grasp the meaning and metaphorics of Toribe as one of few necropolistic sites that have become a motif of literary works since the Heian period (794-1192). In order to develop a possible interpretation of selected excerpts from the literary works as well as the necropolis itself, the author focused especially on its toponymic aspect. On the other hand, detailed study of Toribe motif as a topos let the author approach a few possible ways of its interpretation as a complex metaphor, but also from the point of view of its stylistic function.
\end{abstract}

Tematyka wanitatywna (łac. vanitas 'marność', heb. hebel 'przemijanie', 'podmuch wiatru' $)^{2}$ wywierała wpływ na polską i europejską tradycję literacką przez wiele stuleci. Refleksja nad nietrwałością życia i przemijaniem była obecna w Europie już w XII i XIII wieku, kiedy powszechnie przypominano: Memento mori! („Pamiętaj o śmierci!”) i pisano utwory skłaniające do przemyśleń nad tymi ponurymi tematami. Szczególne nasilenie zainteresowania sprawami ostatecznymi przypada jednak na wiek XIV i XV, czasy niepokojów, epidemii i wojen. Ówczesne teksty o śmierci jeszcze dobitniej uświadamiały człowiekowi, że każdy jest wobec niej równy (Libera, Pietrusiewicz, Rytel 39-42). Pełne pesymizmu słowa trafiały do gustu również Europejczyków żyjących w okresie baroku (XVII w.). Przypominały o nietrwałości wszechrzeczy, podkreślając, że jedynymi nieśmiertelnymi wartościami ludzkimi są miłość i cnota ${ }^{3}$.

Również w japońskiej literaturze dworskiej wczesnego średniowiecza ${ }^{4}$, która najczęściej poruszała kwestie związane z życiem arystokracji i opisywała piękno

2 Termin ma związek z myślą przewodnią jednej z ksiąg należących do pism dydaktycznych Starego Testamentu - Księgi Koheleta (Eklezjastesa) - rozważaniami nad sensem życia ludzkiego. To właśnie z Ksiegi Koheleta pochodzi słynne zdanie „Vanitas vanitatum et omnia vanitas” („marność nad marnościami wszystko jest marnością", Koh 1,2). Biblia Tysiaclecia. Pismo Święte Starego i Nowego Testamentu 838.

${ }^{3}$ Szerzej zob. Goliński, Janusz. Vanitas: o marności w literaturze $i$ kulturze dawnej. Warszawa: Towarzystwo „Ogród Ksiąg” 1996; Künstler-Langner, Danuta. Idea vanitas, jej tradycje i toposy w poezji polskiego baroku. Toruń: Wydawnictwo Uniwersytetu Mikołaja Kopernika, 1996.

${ }^{4}$ Japońska literatura dworska i arystokratyczna (jap. ōchō bungaku), zgodnie z uniwersalistyczną periodyzacją przyjętą $\mathrm{w}$ większości opracowań naukowych poświęconych piśmiennictwu i historiografii japońskiej, zaliczana jest do starożytności (jap. kodai, jōdai), która trwała do schyłku okresu Heian (794-1185). Po niej dopiero nastąpiło średniowiecze (jap. chūsei), które trwało od końca XII do XVI w. Por. 
przyrody, możemy odnaleźć wątki eschatologiczne. Nie była to tematyka szczególnie często podejmowana przez ówczesnych autorów, ale istniejące wzmianki o śmierci bliskiej lub ważnej osoby, o ceremoniach pogrzebowych, sposobie i miejscu kremacji czy pochówku, pozwalają lepiej zrozumieć stosunek japońskich elit wczesnego średniowiecza do życia i śmierci. Magalena Szajowska zauważa na przykład, że w okresie Heian „[...] koniec życia wywoływał uczucie pustki, rozpaczy i żalu, ale nie gniewu czy sprzeciwu. Rozumiano, że z losem (sukuse) nie można walczyć, a śmierci nie da się pokonać. [...] Śmierć, nawet od dawna spodziewana, była szokiem dla bliskich, powodowała wielki żal i rozpacz" (Szajowska 97-98). Dla podkreślenia jej ostatecznego charakteru ciało zmarłego było najczęściej poddawane kremacji ( $k a s o \overline{)}$, co zgodnie z buddyjską zasadą miało doprowadzać do całkowitej dezintegracji fizycznej natury człowieka (Morris 1973: 112-113).

Tradycyjnym i jednym z trzech głównych miejsc palenia zwłok członków rodziny cesarskiej i arystokracji (tzw. sandaisōsōchi) - obok Rendaino na północny i Adashino na zachodzie - była Równina Toribe (Toribeno), która leżała u stóp Góry Toribe (Toribeyama) na wschodnich peryferiach stolicy Heian (Heiankyō, obecne Kioto $)^{5}$. Ten szczególny teren był nie tylko „bramą" z tego do tamtego

Kotański 1961a: 11; Melanowicz 1994: 20; Melanowicz 2011: 18. Należy jednak uwzględnić fakt, że twórczość literacka późnej starożytności (kodai kōki), rozwijająca się głównie w stolicy Heian, jest również nazwana literaturą wczesnego średniowiecza (chüko), zaś sama stolica - nie tylko w odczuciu ówczesnych Japończyków - była jednym z najwspanialszych centrów kulturalnych śr e d ni ow ie cznego świata (por. Melanowicz 1994: 118-119; Melanowicz 2011: 52-53). Część literaturoznawców również skłania się ku opinii, iż o średniowiecznej literaturze japońskiej można mówić znacznie wcześniej niż od końca XII w. Amerykański uczony Robert N. Huey z University of Hawaii at Mānoa uważa, że średniowiecze w obrębie literatury japońskiej rozpoczęło się około $1080 \mathrm{r}$. (por. Huey 651-668). Pomocne są także badania historyków, którzy dostrzegają procesy i zjawiska społeczne, ekonomiczne i polityczne typowe dla okresu feudalnego (a te zgodnie z powszechną opinią zostały zapoczątkowane wraz z pierwszymi rządami wojskowych) w okresie znacznie wcześniejszym niż od końca okresu Heian. John W. Hall i Jeffrey P. Mass twierdzą, że japońskie średniowiecze obejmuje nie cztery czy pięć stuleci a "siedem ważnych wieków”, począwszy od VIII w. Według badaczy "decentralizacja rozwijających się instytucji średniowiecznej Japonii [...] miała miejsce [już] we wczesnym okresie Heian", a "'powstanie [klasy] bushi' w środkowym okresie Heian odbyło się w ramach struktury, w której prywatne interesy arystokracji dworskiej i arystokracji wojskowej opierającej się na arystokracji prowincjonalnej były zasadniczo powiązane" (Hall, Mass xiii). W niniejszym artykule sformułowanie "literatura dworska wczesnego średniowiecza” odnosi się do głównie do twórczości literackiej z okresu chūko (Heian); autor uwzględnia również pisarstwo z początku chūsei (Kamakura).

${ }^{5} \mathrm{~W}$ okresie Yamato (VI-VII w.) władcy wielokrotnie przenosili swoje siedziby do nowych miejscowości. Dopiero stabilizacja władzy i promulgacja kodeksu Taihō (702 r.) przyśpieszyły budowę stałej stolicy. Cesarzowa Genmei (661-721; panowała w latach 707-715) w roku 708 wydała dekret o budowie nowej siedziby, do której przeprowadzka z Fujiwary odbyła się dwa lata później. Nowe miasto stołeczne Nara, zwane również Heijōkyō (Stolica Pokoju), jako pierwsze w historii było zbudowane w oparciu o plany stolicy Tangów - Chang'an. Nara była stolicą Japonii do 794 r., kiedy to urzędy centralne przeniesiono do obfitującej w wodę doliny otoczonej górami porośniętymi górami - 
świata, ale funkcjonował jako rodzaj metafizycznego, a jednocześnie efemerycznego miejsca spotkań żywych z umarłymi. W takim właśnie kontekście równina Toribe funkcjonowała jako nekropolia. Była "miastem umarłych”, po którym jednak nie pozostały nawet najprostsze groby.

Toribe nabrało szczególnego znaczenia również w literaturze. Począwszy od okresu dworskiego (do XII w.) metafora życia ulotnego niczym dym unoszący się nad równiną Toribe stała się toposem, który wyrażał smutek i poczucie przemijalności rzeczy świata doczesnego (mujōkan). Dym powstający podczas kremacji zaczął symbolizować to samo, co krople rosy na źdźbłach trawy na Równinie Adashi. Obie te metafory zapadły głęboko w świadomość ówczesnych Japończyków i przez kilka stuleci wykorzystywane były przez twórców dla poetyckiego wyrażania idei $m u j \bar{o}^{6}$. W niniejszym artykule autor zamierza przedstawić, w jakim stopniu średniowieczna japońska literatura dworska nawiązywała do kwestii eschatologicznych, szczególnie w kontekście wątków nekropolicznych. Odwołując się do licznych zabytków literackich, autor postara się przeanalizować przede wszystkim topos Toribe, nie tylko w jego toponimicznym znaczeniu jako miejsce kremacji, ale także ujęciu metaforycznym i stylistycznym.

\section{Idea $m u j \bar{o}$}

Góra Toribe, która wznosi się nieopodal świątyni buddyjskiej Kiyomizu (jap. Kiyomizudera) w obrębie dziejszego Kioto, przynależy oficjalnie do tzw. „Higashiyama sanjūroppō” („36 szczytów Wschodnich Gór”)7. Góra ta, wraz z rozciągającą się u jej podnóży równiną o tej samej nazwie, była znana jako miejsce pozbywania się zwłok już na przełomie VIII i IX wieku8. Położone w sporej odległości od

nowego miasta Heiankyō (Stolica Pokoju i Spokoju; późniejsze Kioto), które pozostawało oficjalną stolicą Japonii aż do $1868 \mathrm{r}$.

${ }^{6}$ Pojęcie mujō (skr. anitya) stanowiło jeden z podstawowych buddyjskich terminów teologicznych, zarówno w buddyzmie mahajanistycznym, jak i hinajanistycznym, oznaczał nietrwałość, niestałość, skończoność wszystkich bytów, uwikłanie w niekończące się inkarnacje, nieodłącznie związane z cierpieniem, których kresem mogło być jedynie dostąpienie nirwany (skr. nirvāa, jap. nehan, 'wyzwolenie od cyklu narodzin i śmierci, czyli sasāra'). W buddyzmie hinajanistycznym ta koncepcja teologiczna była wyrażana w postaci tetrady ideograficznej shogyōmujō ‘wszystkie byty są nietrwałe'.

${ }^{7}$ Ogólne określenie na pasmo wzgórz i szczytów widoczne po wschodniej stronie Kioto. Jako pierwszy liczbę 36 szczytów zaproponował Rai San'yō (1780-1832) - historyk, myśliciel, sinolog miłośnik panoramy Wschodnich Gór (Higashiyama), który wzorował się na „36 szczytach Songshan (jap. Sūzan)" położonych w chińskiej prowincji Henan. Najstarszym źródłem przekazującym tę nazwę jest jednak Karaku meishō zue (Ilustracje słynnych miejsc wspaniałej stolicy, 1864) autorstwa Akatsuki Kanenari, Umegawy Tōkyo i in. (Akatsuki et al. 11).

${ }^{8}$ Najstarszy odnotowany pogrzeb na Toribe odbył się w 3 roku Tenchō $(826$ r.) po śmierci księcia Tsuneyo, pierworodnego syna cesarza Junna (786-840; panował w latach 823-833). Od tamtej pory 
granic stolicy i z dala od domostw stanowiła początkowo idealne miejsce, gdzie przyniesione ciało mogło być zwyczajnie porzucone i pozostawione na pastwę natury (było to tzw. fūsō 'pogrzeb przez [pozostawienie zwłok, aż się rozpadną, a jego resztki rozwieje] wiatr'). Dopiero wraz z powstaniem nowych sekt buddyjskich ${ }^{9}$ i szerzeniem się ich nauk zaczął się zmieniać stosunek społeczeństwa do problemu obchodzenia się ze zwłokami. Znany reformator religijny i założyciel sekty Shingon (prawdziwe słowa) - Kūkai (774-835; pośmiertne imię Kōbō-daishi), kiedy w 811 roku przybył pod Toribe, nauczał okolicznych mieszkańców, że należy chować zmarłych i się za nich modlić10. Od tamtej pory ciało zmarłej osoby zaczęto traktować $\mathrm{z}$ większym szacunkiem, rytualnie je grzebiąc lub spopielając. $\mathrm{Z}$ różnych względów to właśnie kremacja stała się najpopularniejszą formą "pochówku", gdyż niewątpliwie zdawała się najpełniej wyrażać buddyjską ideę niestałości wszechrzeczy (mujō).

Kremacja - wizualny efekt odchodzenia, ulotności materii, z której zbudowany jest człowiek - miała głównie wymiar religijny. Znalazła jednak wyraz w literaturze i sztuce, gdzie stała się jednym z najważniejszych wyznaczników estetyki japońskiej okresów Heian i Kamakura (IX-XIV w.). Termin mujō pojawia się w literaturze japońskiej dość wcześnie, bowiem już w pierwszej antologii rodzimej poezji - Man'yōshū (Dziesięć tysięcy liści, ok. 780). Wspomina o tym w swoim artykule Krzysztof Olszewski:

Oto w księdze 16. antologii zamieszczone są dwa wiersze (pod numerem 3849 i 3850) opatrzone komentarzem: Wiersze te byty zapisane na instrumencie koto w głównym pawilonie w światyni Kawara. We wstępie kotobagaki do pierwszego z tych wierszy czytamy: Dwie pieśni wyrażajace ubolewanie nad niestałościa tego świata. I choć samo słowo mujō nie pojawia się w kolejnych dwóch utworach mających metrum krótkiej pieśni japońskiej

coraz więcej arystokratów było tam grzebanych i kremowanych, przez co Toribe zyskało charakter nekropoliczny (Funo, Watanabe 2001: 193).

${ }_{9}^{9}$ Buddyzm, który dotarł do Japonii w VI w., zyskał szczególnie na znaczeniu dopiero w okresie Nara (710-794). Wtedy właśnie uformowało się sześć głównych szkół (sekt) - trzy mahajanistyczne: sanron, hossōshū, kegonshū, i trzy hinajanistyczne: jōjitsu, kusha, ritsushū, a ich różnice doktrynalne wynikały z niezależności poszczególnych klasztorów. Kapłani służyli głównie dworowi i arystokracji, którzy korzystali z ich usług podczas sprawowania obrzędów i modłów o pokój i pomyślność, a także w sprawach osobistych (odczynianie uroków, zaklęcia etc.). Większa popularyzacja buddyzmu nastąpiła jednak na początku okresu Heian, kiedy powstały dwie nowe sekty: shingon i tendai. Cechujący je synkretyzm, łączący buddyzm z shintoizmem, bogatsza ikonografia i ceremoniał szybko zyskały akceptację kleru i arystokracji. Szerzej na temat nowych sekt zob: Varley 50-55.

${ }^{10}$ Wynikało to z poglądu, że wielkie żywioły wszechświata (ziemia, woda, ogień, wiatr, przestrzeń i świadomość) tworzą buddów i zwykłe istoty. Przemieszane żywioły w wieczystym stanie harmonii, czyli ciało przepełnione namiętnością, to ciało identyczne jak oświecone ciało Buddy. Interpretacja tego poglądu doprowadziła również do takich praktyk jak mumifikowanie i oddawanie czci ciałom (McGreal 380). 
tanka, to jednak za pomocą różnych obrazów poetyckich wyrażają one po raz pierwszy w literaturze japońskiej to przekonanie, które miało stać się ważną dominantą estetyczną w sztuce japońskiej w kolejnych wiekach ${ }^{11}$.

Doskonałym wyrazem idei mujō jest również powstały prawdopodobnie na początku X wieku utwór pt. Iroha [uta] ([Pieśń] iroha12). To właśnie ten wiersz, oparty na Sutrze Nirwany (skr. Mahāparinirvāa Sütra, jap. Nehankyō) i funkcjonujący jako rodzaj abecadła ${ }^{13}$, był jednym z pierwszych tekstów, jakich uczyły się dzieci poczynając od okresu Heian. Utwór ten brzmi następująco:

Iro wa nioedo/ Chirinuru o/ Waga yo tare zo/ Tsune naran/ Ui no okuyama/ Kyō koete/ Asaki yume miji/ Ei mo sezu.

Choć barwne jest kwiecie, w końcu oblatuje. Nikt na tym świecie nie może żyć wiecznie! Przekraczając dziś górskie załomy karmy, płytkich snów nie zobaczę i upoić [rozkoszami świata tego] się nie dam ${ }^{14}$.

Ten najpopularniejszy akrostych starojapoński, zawierający w sobie buddyjskie przesłanie o niestałości doczesnego świata, głosi konieczność odrzucenia przyziemnych blasków, które zbledną niczym barwne kwiecie, i podążania drogą karmy aż do osiągnięcia nirwany. To właśnie sens retorycznego stwierdzenia: „Nikt na tym świecie nie może żyć wiecznie!" (waga yo tare zo tsune naran) wyraża

${ }^{11}$ Ze względu na środki wyrazu poetyckiego szczególnie pierwszy ze wspomnianych wierszy zasługuje na uwagę: „Pośród życia i śmierci/ Oceanów otchłani/ Jakże okrutnej - / Wymarzę sobie górę,/ Której nie lizną fale?". Krzysztof Olszewski interpretuje ten wiersz w następujący sposób: "życie i śmierć człowieka, wraz z wpisanym do niego odwiecznym prawem karmy warunkującym ciąg niekończących się inkarnacji zostały w tym wierszu wyrażone za pomocą alegorii dwóch oceanów, pośrodku których podmiot liryczny pragnie wymarzyć sobie górę, której nie liznęłyby fale przypływu, gdzie człowiek wolny byłby od cierpienia ciągłych wcieleń, gdzie mógłby - być może dostąpić nirwany. Jednocześnie przypływające i odpływające fale, które w mgnieniu oka [...] zmywają wszystko ze skał, są w tym utworze alegorycznym przedstawieniem teologicznej koncepcji mujō. Warto jeszcze zwrócić uwagę na symbolikę góry w omawianym utworze. Góra - od dawna w mitologii chińskiej miejsce święte, poświęcone bogom [...] jawi się jako jedyny trwały, stały element tego świata, jako nadzieja i ucieczka dla człowieka w obliczu grozy „życia i śmierci [dwóch] oceanów”. Jednocześnie góra jest często pojawiającą się w klasycznej poezji japońskiej alegorią dalekiej i trudnej drogi człowieka do osiągnięcia satori, oświecenia buddyjskiego" (Olszewski 243-244).

12 Iroha to tytuł pangramicznego wiersza z okresu Heian; zawiera wszystkie 47 zgłosek japońskiego sylabariusza kana. Pierwszy znany zapis poematu pochodzi z 1079 r., a jego autorstwo przypisywane jest Kūkaiowi (Fujimura, Nishio 292).

${ }_{13}$ Popularność na przestrzeni stuleci właśnie tego wiersza sprawiała, że jeszcze w XX w. wiele japońskich słowników bazowało na porządku haseł zgodnych z kolejnością poszczególnych sylab Iroha uta. Współcześnie kolejność ta jest wykorzystywana m.in. do wyliczania, numerowania podpunktów $\mathrm{w}$ tekstach etc.

14 Przekładu wszystkich cytowanych fragmentów, o ile nie zostało podane inaczej, dokonał autor. 
istotę mujō. Również alegoryczne przedstawienie dążeń człowieka do osiągnięcia nirwany jako przekraczania "górskich załomów karmy" stanowi część jednej wielkiej metafory efemeryczności życia na ziemskim padole (Olszewski 245).

\section{Wpływ koncepcji mujō na średniowieczną literaturę}

Koncepcja mujō, którą dogłębnie przesiąknęła literatura okresu Heian i okresów późniejszych (XIII-XIV w.), była obrazowana w różny sposób. Jako buddyjska wersja memento mori odwoływała się bynajmniej nie do przerażających scen nasyconych naturalizmem i turpizmem ${ }^{15}$, ale wręcz przeciwnie - do żywych i barwnych obrazów przekwitających kwiatów, zmieniających ubarwienie jesiennych liści czy kropli rosy na źdźble trawy. Przykładem takiego postrzegania niepewności i przemijalności może być fragment z Izumi Shikibu nikki (Pamiętnik Izumi Shikibu, 1003):

Kiedy patrzę na rośliny żałośnie uginające się na wietrze, z niepokojem myślę o moim życiu - równie nietrwałym jak te krople rosy, które za chwilę zdmuchnie wiatr. Widok tych drzew i roślin budzi żal i przywodzi na myśl mój własny byt ${ }^{16}$. (Izumi 420)

To otaczająca człowieka natura pozwala mu dostrzec, że wszystko jest kruche i ulotne. Szczególnie, jeśli ujrzymy coś pięknego, co zaraz marnieje i ginie, najpełniej pojmujemy ideę mujō.

Oto jeszcze jeden głos w dyskusji nad nietrwałością życia doczesnego, wyrażony przez Kamo no Chōmeia (1154?-1216) w jego zbiorze esejów Hōjōki (Zapiski z pustelni, 1212). Autor zawarł w nim następujące przemyślenia:

Rzeka w swym biegu jest nieprzerwana, ale to nie jest wciąż ta sama woda. Piana wezbrana na zakolach to znika, to się znów gromadzi, i nie zdarza się, by pozostawała dłużej. [...] To samo z ludźmi [...] rankiem umierają, a wieczorem się rodzą, zupełnie jak piana na płynącej wodzie.

Nie wiemy, skąd przychodzą ludzie na ten świat i dokąd z niego odchodzą, kiedy umierają. Nie wiemy też, dla kogo się dręczymy budując nasze nietrwałe doczesne schronienie, i dlaczego cieszymy oczy jego widokiem. Losy ludzi i ich domów - które $\mathrm{z}$ nich najbardziej niepewne? - nie różnią się niczym od rosy na kwiecie powoju. [...]

15 Jest to oczywiście uproszczenie, gdyż w rzeczywistości w literaturze okresu Heian znajdujemy opisy np. porzuconych zwłok. Podobnie, jak i w malarstwie, gdzie nie szczędzono środków wyrazu, aby uchwycić poszczególne etapy śmierci czy rozkładu ciała. Przykładem takiego dzieła literackiego ukazującego również buddyjską wersję motywu vanitas - może być Tamatsukuri Komachi sōsui sho (Chwała i upadek Komachi, która hodowała perty, koniec X w.). Ta historia była również wielokrotnie ilustrowana (np. słynne Kusōzu ‘Ilustracje dziewięciu etapów [rozpadu zwłok Ono no Komachi]'). Por. Faure 273-279; Nishiyama 120-127.

16 Przekł. za: Morris 1973: 115. 
Ciężko jest żyć na tym świecie, gdzie i ludzie, i ich domy tak właśnie trwają krótko i tak szybko przemijają. (Kamo 21, 25)

Odpowiedź na postawione w tym fragmencie pytanie: „Losy ludzi i ich domów - które z nich najbardziej niepewne?” zdaje się oczywista: „nie różnią się niczym od rosy na kwiecie powoju". Przedstawienie egzystencji jako kropli rosy, która jest - o czym już wspomniano - kolejną metaforą efemeryczności, to jednocześnie ukazywanie $\mathrm{w}$ jakiś stopniu wycinka duchowości ówczesnego społeczeństwa, które miało świadomość, że wszystko, co istnieje, jest nietrwałe. Istotę tej duchowości wyrażają explicite jeszcze inne, słynne słowa rozpoczynające wielkie dzieło Heike monogatari (Opowieść o rodzie Taira, ok. 1220):

Dźwięk dzwonu z klasztoru Gion ${ }^{17}$ echem jest niestałości wszechrzeczy, a barwa kwiecia drzewa shara ${ }^{18}$ zwiastuje nam tę prawdę, że cokolwiek rozkwita, niezawodnie szczeźnie. Buta człowieka tak krótko trwa jak w noc wiosenną marzenie senne, a kto waleczny, też wprędce przepadnie, zupełnie jako pył w podmuchu wiatru ${ }^{19}$. (Heike 83)

Ta literacka historia potężnego rodu, który dostał się na wyżyny dworskie tylko po to, by spotkała go dotkliwa klęska i zagłada w pięcioletniej wojnie z członkami rodu Minamoto, pokazuje, że wszyscy możni „przepadną jak pył w podmuchu wiatru" (Varley 80-82). W rzeczywistości odnosi się to nie tylko do ludzi potężnych i posiadających władzę, lecz dotyczy każdego bytu na ziemi. Wszystko, co "rozkwita, niezawodnie szczeźnie” (oryg. jōsha hissui), a ostatecznym wyrazem tej prawdy będzie kremacja. Wówczas ciało zmieni się w dym i uleci ze świata przepełnionego cierpieniem (Szajowska 101-102).

\section{Obrazy toribe a natura ludzkiej egzystencji}

Nie tylko te najdelikatniejsze, najszybciej marniejące, a przez to wzruszające - wyrażane nierzadko kategorią estetyczną aware ${ }^{20}$ - elementy świata przyrodni-

\footnotetext{
${ }^{17}$ Japońskie odczytanie nazwy jednej z najsłynniejszych monasterii buddyjskich $\mathrm{w}$ Indiach Jetavana.

18 Shara (sanskr. śäla) - polska nazwa systematyczna: dmarzyk mocny (Shorea robusta) - to wiecznie zielone drzewo pochodzące z Indii, które pojmowane jest jako symbol nietrwałości. Podobno sam Budda Śākyamuni odszedł w gaju, w którym rosły shara.

19 Przekł za: Kotański 1961a: 348.

${ }^{20}$ Morris pisze, że w Genji monogatari słowo to stosowane jest dla „określenia patosu właściwemu pięknu świata zewnętrznego, pięknu nieuchronnie skazanemu na przemijanie, podobnie jak na przemijanie skazany jest ten, który na nie patrzy. [...] bohaterowie tej opowieści przeżywają bezpośrednio i głęboko zmienność równoznaczną z bezpowrotnym odchodzeniem rzeczy. [...] na styku czasu "przyrodniczego", cyklicznego, nastrajającego bohatera raczej nadzieją, i nurtu czasu ludzkiego, jakim
} 
czego miały obrazować przemijanie. Odwołania do kwiatów sakury21 czy kropli rosy na trawie, choć pełne liryzmu, nie oddawały jednak w całości ludzkiego odchodzenia. Niewątpliwie egzystencja porównywana do pyłu niknącego w podmuchu wiatru, a więc jak ludzkie prochy, a także dym powstający podczas kremacji zwłok, stały się bardziej wymowną metaforą tej koncepcji. Być może dla podkreślenia głębszego sensu tej metafory zaczęto bezpośrednio nawiązywać także do Toribe. Odtąd nazwa tej nekropolii stała się elementem wyrażenia Toribeyama (lub Toribeno) no kemuri22 (dym [unoszący się nad] Górą [lub Równiną] Toribe), co można sparafrazować jako „dym nekropoliczny”, czyli - mówiąc inaczej - „dym toribe-ński". Określenie to stało się najbardziej sugestywną i przemawiającą do ludzkiej wyobraźni werbalizacją koncepcji mujō. Potwierdzeniem tej tezy jest chociażby fragment ze znanego utworu z gatunku sylw zuihitsu (dosł. podług pędzla) pt. Tsurezuregusa (Szkice z wolnych chwil, ok. 1330) autorstwa Yoshidy Kenkō (1283?-1350). Autor pisze następująco:

Adashino no tsuyu kiyuru toki naku, Toribeyama no keburi tachisarade nomi sumihatsuru narai naraba, ikani, mono no aware mo nakaran.

Gdyby na równinie Adashi [z źdźbeł trawy] nie opadła rosa, a nad Toribe nie rozwiałby się dym, a więc żyłoby się wiecznie, czyż nie byłoby to smutne i żałosne? (Hosaka 23)

Kenkō, pisząc $\mathrm{w}$ formie metafory o (potencjalnie) nierozwianym dymie toribeńskim, ma oczywiście na myśli bezkresne życie. Podobnie jednak, jak nie istnieje rosa, która mogłaby przetrwać i utrzymywać się wiecznie na źdźbłach trawy, wiatr z czasem rozwieje nad „nekropolią” kremacyjny dym. Urodziliśmy się, więc

jest przeżywanie bolesnych emocji [...] rodzi się koncepcja mujō - „nie-trwałości” i mujōkan, czyli poczucie nietrwałości jako swoistej filozofii życia" (Morris 1973: 191).

${ }^{21} \mathrm{Na}$ początku okresu Heian, kiedy Japonia utrzymywała jeszcze bliskie stosunki z Chinami za dynastii Tang (618-907), w modzie było podziwianie kwiatów śliwy (ume). Jednak po roku 894, kiedy to oba państwa zerwały stosunki dyplomatyczne, stopniowo to kwiaty drzewa wiśni, czyli sakura, stawały się bardziej popularne (na temat historii związanej z kwiatami sakury zob. Conder 18). Ale to tylko jeden z powodów, dla których sakura zagościła na dobre w sercach Japończyków kilkanaście wieków temu. Jak zauważa Donald Keene: „Prawdopodobnie kwiaty śliwy zostały zastąpione przez wiśnie z powodów estetycznych, ponieważ pozostają na gałązkach przez długie tygodnie, podczas gdy kwiaty wiśni w sposób dramatyczny opadają po dwóch, trzech dniach. Przemijalność piękna zawsze poruszała do łez i [...] dla pojęcia piękna stała się wręcz nieodzowna. Niezliczone wiersze na temat kwiatów wiśni rzadko opowiadają o ich pojawieniu się. I dla tych, którzy je obserwują, są wyraźnymi symbolami przemijającej urody" (Keene 93). Zatem to krótkotrwałe piękno kwiatów sakury zauroczyło starożytych Japończyków, a nawet podniosło jeszcze jego wartość. (Conder 17). Można stwierdzić - odwołując się do Genji monogatari (Opowieść o księciu Genji, 1008) - że to „sakura pouczy ludzi o tym, że świat jest przemijający, jak opadające szybko wiosenne kwiaty i czerwone jesienne liście" (Murasaki 1972: 287). Przekład powyższego fragmentu za: Morita 165.

22 Również w formie keburi. 
odejdziemy, gdyż „byłoby to smutne i żałosne” (mono no aware), jeśli żylibyśmy wiecznie na tym świecie pełnym cierpienia.

Przywołanie $\mathrm{w}$ powyższym fragmencie buddyjskiej koncepcji niestałości wszechrzeczy (mиjō) poprzez alegoryczne przedstawienie „dymu nekropolicznego", który był kojarzony głównie z Toribe, stanowi jedynie wprowadzenie do dalszych rozważań nad rolą i symboliką tego toponimu w twórczości japońskich autorów wczesnego średniowiecza. W jakich zatem kontekstach, szczególnie literackich, pojawia się nazwa Toribe?

Po przeniesieniu w 794 roku stolicy z Nary do Heian, do miasta stołecznego napływało coraz więcej ludzi. Sprzyjało to eskalacji głodu i rozwojowi epidemii. Nierzadko stolica, nękana dodatkowo klęskami żywiołowymi, była usłana niezliczoną ilością ciał zmarłych (Shintani 54). Literacki opis takich obrazów zachował się między innymi w dwudziestodziewiątym rozdziale Konjaku monogatari (Dawno temu - opowieści, pocz. XII w.) ${ }^{23}, \mathrm{w}$ opowiadaniu zatytułowanym Rashōmon ni uwakoshi ni noborite shinin o miru nusuibito no koto (O złodzieju, który wspiął się na poddasze Bramy Demonów i spoglądał na trupa). Utwór przedstawia wzbudzającą niesmak historię staruchy wyrywającej włosy trupom porzuconym w głównej bramie miasta - Rashōmon (dosł. Brama Demonów) ${ }^{24}$. Opisana w opowiadaniu sytuacja jest jednym z wielu negatywnych skutków braku odpowiedniej kontroli czystości stolicy przez ówczesne władze miasta i usuwania ciał zmarłych osób. Bez wątpienia nie było to spowodowane brakiem norm prawnych, gdyż już kodeks Taihō (Taihō ritsuryō), promulgowany w 702 roku $^{25}$, zawierał przepisy regulujące sprawy związane z żałobą po zmarłym i jego pochówku (sōsōryō), które jednoznacznie określały, że zwłoki muszą być bezwzględnie grzebane poza obrębem zabudowań, w miejscach oddalonych od stolicy ${ }^{26}$.

${ }^{23}$ Zbiór ponad tysiąca krótkich anegdot i opowieści o niezwykłych wydarzeniach zebranych w 31 tomach; autor (lub kompilator) jest nieznany. Przekład księgi XXVII na j. polski zob. Japońska ksiega duchów i demonów. Zbiór historii dawnych i obecnych - Konjaku monogatari. Przeł. Renata Iwicka. Toruń: Kirin, 2013.

24 Identyczny motyw kobiety bezczeszczącej zwłoki znajdziemy również w rozdziale 31. Przy okazji, warto tutaj wspomnieć, że na kanwie rzeczonej historii jeden z najwybitniejszych pisarzy japońskich XX wieku Akutagawa Ryūnosuke (1892-1927) napisał opowiadanie Rashōmon (1917), który w utworach o tematyce historycznej sięgał do źródeł pisanych okresu dworskiego, ale szczególne "piękno odkrył w Opowieściach wspótczesnych $i$ dawnych [Konjaku monogatari] z XII wieku” (Akutagawa 13-19).

${ }^{25}$ Kodeks Taihō składał się z dwóch części: ritsu, czyli prawa karnego (ustanawiał ogólne normy prawne obowiązujące ówczesnych Japończyków), oraz ryō, czyli postanowień administracyjnych (powoływał i reorganizował centralne i prowincjonalne urzędy). Choć był wzorowany na rozbudowanej, kosztownej biurokracji i prawie państwa Tangów, świadczył o rozwiniętym w pełni nowym rządzie, rezydującym w Narze (Hall 48-52).

${ }^{26}$ Szerzej na ten temat zob. Inada 1607-1640. 
We wczesnym okresie Heian jednym z największych i najpopularniejszych miejsc funeralnych było Toribe, gdzie - zgodnie z buddyjskim zwyczajem - palono zwłoki, choć zdarzały się również tradycyjne pochówki w grobach $(\text { dosō })^{27}$. Kremacji dokonywano często zgodnie z wolą umierającego (oczywiście pod warunkiem, że zdążył ją wcześniej wyrazić). Przykładowo Teishi (977-1001), małżonka cesarza Ichijō (980-1011; panował w latach 986-1011), zostawiła po sobie „testament", w którym wyraziła wolę dotyczącą sposobu postępowania z jej zwłokami po śmierci. W swoim „wierszu-testamencie” napisała:

\author{
Keburi to mo \\ kumo to mo naranu \\ mi nari to mo \\ kusaba no tsuyu o \\ sore to nagameyo \\ Ani dymem, \\ ani chmurą się nie stanę, \\ lecz popatrzcie \\ na rosę na liściach trawy \\ i pomyślcie o mnie ${ }^{28}$. (Eiga 217)
}

Teishi dokonała świadomego wyboru, o którym poinformowała w niezwykle wyrafinowany - choć w czasach dworskich bardzo oczywisty - sposób, czyli komponując wiersz. Cesarska małżonka chciała, aby po śmierci jej ciało nie stało się "ani dymem, ani chmurą" (keburi to mo kumo to mo), a śmierć przypominała jedynie "rosę na liściach trawy" (kusaba no tsuyu).

Zawoalowana sugestia Teishi, jak się dowiadujemy z Eiga monogatari (Opowieść o rozkwicie, XI w.), została trafnie odczytana przez członków jej rodziny, o czym mówi poniższy fragment:

Korechika wnioskując z ostatniego wiersza Teishi, że ta nie chce, aby jej zwłoki spalono, zarząaził przygotowania do pochówku. Na cmentarzu zbudowano grobowiec na trumnę, który był otoczony nasypem z ziemi w miejscu oddalonym o około dwieście metrów na południe od równiny Toribe. (A Tale of Flowering Fortunes 232)

Tekst przedstawia dokładny opis miejsca pochówku cesarzowej - na skraju równiny Toribe. Lokalizacja grobu na obrzeżach nekropolii wynikała z chęci uniknięcia „zagęszczenia” centralnej części równiny mogiłami, gdyż - jak wiadomo Toribe pełniła jednocześnie rolę „krematorium” na otoczonej przyrodą otwartej

27 Przykładem są pochówki Kishi (zm. 997) - małżonki cesarskiego kaclerza, a także Teishi - żony cesarza Ichijō, których opisy znajdziemy w Eiga monogatari.

${ }^{28}$ Przekł. za: Szajowska 99. 
przestrzeni. Potwierdzeniem tego faktu jest opis ceremonii pogrzebu matki cesarza Ichijō - Senshi (962-1002). W Eiga monogatari znajduje się następująca relacja tego wydarzenia:

Data śmierci Senshi to 22. dzień 12. miesiąca 3. roku Chōhō (1002 r.). Było przeraźliwie zimno, a dookoła wysokie śnieżne zaspy. [...] Trzy dni później wyruszył kondukt żałobny do Toribeno. Śnieg padał obficie. [...] Michinaga przewodniczył uroczystościom przez całą noc [...], a o świcie, zebrawszy prochy, zawiózł je do Kohaty i wrócił do rezydencji dopiero po wschodzie słońca. (A Tale of Flowering Fortunes 247-248)

W tym wypadku mamy oczywiście do czynienia z kremacją. Nad ranem, gdy ciało było już spalone, resztki ognia dogaszano dodatkowo winem ryżowym (Szajowska 99). Następnie ktoś z żałobników (tu taką osobą był Fijiwara no Michinaga $^{29}$ ) przenosił prochy do Kohaty (obecnie północna część miasta Uji na południe od Kioto), gdzie tradycyjnie chowano prochy członków najpotężniejszego podówczas rodu Fujiwara (Inada 98).

Zastanawiać może, dlaczego Teishi nie chciała, aby jej zwłoki zostały skremowane. Może wizja płomieni, które będą trawiły jej ciało po śmierci kojarzyła się z wizjami buddyjskiego piekła (skr. naraka, jap. jigoku) i była bardziej przerażająca niż świadomość, że w grobie ciało zacznie gnić i będzie toczone przez robactwo? Trudno odpowiedzieć na to pytanie, lecz to nie grzebanie ciała, a właśnie praktyka palenia zwłok potęgowała poczucie bezsensu i niestałości. Jak powie podczas jednej ze swoich wizyt w Uji młodziutki Kaoru - syn Kashiwagiego i Nyosan z powieści Genji monogatari (Opowieść o księciu Genji, 1008) autorstwa Murasaki Shikibu - „cokolwiek się rzeknie, każdy z nas prędzej czy później musi zamienić się w dym i wzlecieć ku niebu" 30 . Strach przed nieuchronnym losem ogarniał każdego, ale świadomość, że się odchodzi tak szybko, dosłownie z podmuchem wiatru, mogła być jeszcze straszniejsza.

A jak się jawiła najczęściej odwiedzana „nekropolia” ówczesnym mieszkańcom Heian? Złowieszcza atmosfera tego miejsca niewątpliwie silnie pobudzała ludzką wyobraźnię i namacalnie uzmysławiała, że jest to miejsce, do którego nieuchronnie każdy trafi. Kontakt ze śmiercią oznaczał religijne zbrukanie (kegare), dlatego wracając do stolicy z miejsca kremacyjno-pochówkowego, każdy żałobnik poddawał się ablucji w rzece Kamo. W literackich przedstawieniach okolice Toribe są nace-

${ }^{29}$ Fujiwara no Michinaga (966-1028) - arystokrata, polityk i pisarz z okresu Heian. Pełnił najwyższe funkcje urzędnicze w państwie; jego pięć córek zostało żonami władców i książąt krwi, trzy z nich zostały cesarzowymi, a trzech wnuków Michinagi zasiadło na tronie. Autor Midō kanpakuki (Zapiski Wielmożnego Kanclerza), jednego z najstarszych prywatnych dzienników w kanbunie (pismo chińskie odczytywane po japońsku), który został spisany w latach 998-1021.

30 Oryg.: munashiki sora ni nobirinuru keburi nomi koso, daremo, nogarenu koto nagara, okure sakidatsu hodo wa, nao, ito, iukainakarikere (Murasaki 1963: 95; przekł. za: Morris 1973: 116). 
chowane melancholią, a nawet niepokojem. Kiedy książę Genji - tytułowy bohater powieści Murasaki Shikibu - dowiedział się o nagłej śmierci ukochanej Yūgao, od razu wyruszył poza stolicę, aby osobiście się o tym przekonać. Po drodze przejeżdżał przez Równinę Toribe, co narrator utworu opisuje następująco:

Na niebie lśnił księżyc, a było tuż po pełni w 17. dniu miesiąca. Nad brzegiem rzeki tliły się pochodnie straży przednich, $\mathrm{w}$ dali natomiast rozciągała się Równina Toribe. Widok ten nie wydawał mu się aż tak ponury, ale poczuł w sercu niepokój. Tak dotarli do świątyni. Był to surowy i nieprzyjazny teren. (Murasaki 1958: 159-160)

Było już ciemno, kiedy Genji i Koremitsu - „przyszywany” brat księcia - przejeżdżali przez Toribe. Sama świadomość przebywania $\mathrm{w}$ takiej chwili w takim miejscu, którego widok - paradoksalnie z powodu ciemności - nie był aż tak przygnębiający, wywołała w sercu Genjiego zaniepokojenie.

Przedstawiony tutaj obraz Toribe, chociaż ewokuje u bohaterów cytowanych utworów uczucie niepokoju, strachu czy melancholii, jeszcze na początku okresu Heian funkcjonował jedynie jako toponim podobny do nazw innych miejscowości, gór, rzek itp. W środkowym okresie Heian toponim Toribe zaczął jednak być używany z jednej strony jako utamakura (wezgłowie pieśni) ${ }^{31}$, które nawiązywało do znanych miejsc $\mathrm{w}$ okolicach stolicy, ${ }^{32} \mathrm{a} \mathrm{z}$ drugiej również jako rodzaj epitetu, który występował w stałym połączeniu głównie z rzeczownikiem keburi (dym) ${ }^{33}$.

W ostatnim rozdziale Eiga monogatari, zatytułowanym "Tsuru no hayashi" (Żurawi Gaj), dowiadujemy się, że wielki mąż stanu - Fujiwara no Michinaga zmarł 4. dnia 12. miesiąca 4. roku Manju (1028 r.). Jego pogrzeb odbył się nocą 17. dnia. Po całonocnej kremacji i modłach prochy Michinagi zabrano do Kohaty. Jeden z buddyjskich pałacowych kapelanów, niejaki Hōkyō Chūmyō, skomponował wtedy na cmentarzysku taki oto wiersz:

31 Terminem utamakura określamy króciutkie frazy (lub pojedyncze wyrazy), które nawiązują do znanych miejsc historycznych, religijnych, dawnych prowincji, etc. Ich lapidarna forma zawsze zawiera w sobie nazwę przywoływanego miejsca.

32 Porównaj wykaz utamakura dla poszczególnych rejonów Japonii w: Mizukaki, Meisho utamakura ichiran.

${ }^{33} \mathrm{~W}$ tradycyjnej poezji japońskiej taką funkcję pełniły m.in. makurakotoba, która „przypomina nieco klasyczny epitet stały, tzn. wyraz przysługujący danemu rzeczownikowi jako jego stała przydawka (por. u Homera „różanopalca Jutrzenka”). Specyficzną cechą makurakotoba jest, że przysługuje nie tylko określonemu wyrazowi, ale też jego homofonom albo nawet początkowej części dowolnego wyrazu, jeśli jest ona homofoniczny z wyrazem, który jest kwalifikowany do określenia epitetem stałym. Owa kwalifikowana, początkowa część wyrazu czy wersu jest pojmowana przenośnie jako "głowa", a ponieważ epitet stoi w japońskim zawsze przed wyrazem określanym, uważa się, że wyraz ten dotyka swą "głową" do epitetu, a więc epitet funkcjonuje tu jako „wezgłowie" - stąd nazwa „wyraz-wezgłowie” (Kotański 1961b: 133-134). 
Keburi tae
yuki furishikeru
Toribeno wa
tsuru no hayashi no
kokochi koso sur"
Dym uleciał,
a otulona śniegiem
Równina Toribe
oddaje nastrój
Żurawiego Gaju
(A Tale of Flowering Fortunes 2: 768)

Powyższy utwór kryje $\mathrm{w}$ sobie wiele treści związanych $\mathrm{z}$ Toribe. Po pierwsze, występuje w nim często spotykane zestawienie słów keburi (lub kemuri) i Toribe, choć nie w literalnej formie frazy Toribe no kemuri (toribe-ński dym). Użyte w jego miejsce wyrażenie "yuki furishikeru Toribeno" ("otulona śniegiem równina Toribe") wprowadza natomiast pewne zamieszanie, gdyż do tej pory fraza ta nie pojawiła się w żadnym innym tekście. Michinaga, jak już wspomniano, odszedł w 12 . miesiącu, a więc pogrzeb odbywał się $\mathrm{w}$ scenerii zimowej. $\mathrm{W}$ dniu pogrzebu padał śnieg, co wyjaśniałoby, dlaczego w wierszu występuje odniesienie do tego opadu atmosferycznego. Ale to tylko interpretacja oczywistej warstwy znaczeniowej tej frazy. Kluczem do odczytania ukrytej warstwy semantycznej wyrażenia "yuki furishikeru Toribeno" jest "tsuru no hayashi” (Żurawi Gaj). W źródle tej frazy, Sutrze Nirwany, jest ona określeniem miejsca, w którym Budda Śākyamuni dostąpił oświecenia. To w Żurawim Gaju rosły drzewa śâla. Ich opadające białe kwiaty niczym pióra białych żurawi - z czasem szarzały i marniały, a więc ginęły. Poprzez porównanie Toribe do Żurawiego Gaju, topos ten nabrał w pewnym stopniu wymiaru metafizycznego, a nawet sakralnego, gdyż odnosi się do samego Buddy. To jednak nie koniec ukrytych sensów i gier słownych, które były stałym elementem ówczesnej twórczości poetyckiej. Nie bez znaczenia jest doszukiwanie się związku pomiędzy wyrazami Toribe a tsuru (żuraw). W słowie Toribe człon tori oznacza bowiem ptaka, a zatem oba wyrazy mają bardzo zbliżone znaczenie. Sięgnięcie w przytoczonym utworze po obraz Toribe jako Żurawiego Gaju jest więc nie tylko kongenialnym połączeniem toposu nekropolicznego z teologicznymi wyobrażeniami, ale świadczy również o wysoko rozwiniętym warsztacie poetyckim ówczesnych elit kulturalnych.

\footnotetext{
34 Wiersz ten w nieznacznie zmienionej formie można zaleźć także w antologii Goshūishū (Zbiór poezji japońskiej późnego pokłosia, 1086), w części X, wiersz 544, gdzie wspomniano również o okolicznościach jego powstania.
} 


\section{Dym na plaży w suma}

Wracając jednak do podstawowej symboliki Góry/Równiny Toribe, dobrym przykładem ilustrującym ten topos w utworach poetyckich może być epizod opisany w Genji monogatari w rozdziale Suma. Książę Genji, który w wyniku zmian administracyjnych $w$ pałacu został zmuszony do wyjazdu na prowincję, żegnając się z wieloma bliskimi osobami, otrzymał również wzruszające słowa od księżnej Ōmiyi, na które odpowiedział następującym wierszem:

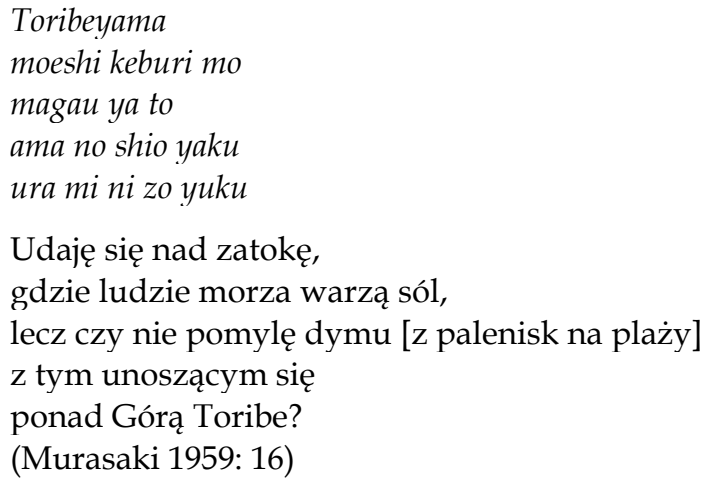

W dawnych czasach widok ludzi żyjących nad brzegiem morza, często kobiet, które zajmowały się poławianiem skorupiaków, zbieraniem i suszeniem wodorostów czy odparowywaniem soli, był czymś oczywistym. Warzenie soli morskiej w kłębach dymu wydobywającego się znad palenisk, dodatkowo wymieszanego z parą wodną, oddziaływało na wyobraźnię mieszkańców stolicy, którzy podobny widok - poprzez skojarzenia - znali głównie z Toribe. Znał go doskonale również Genji, gdyż właśnie na Równinie Toribe zostało skremowane ciało Aoi no Ue jego pierwszej żony, a jednocześnie córki księżnej Ōmiyi.

Kontekst śmierci jego małżonki w szczególny sposób podkreśla również słowo urami, które - jak sugerowałby opis sytuacji - oznacza nadbrzeże zatoki, plażę nad zatoką, zatokę albo też oglądanie zatoki (Ōno 191). Jest to również homonim słowa żal, rozgoryczenie, smutek, który odczuwali po odejściu damy Aoi jej najbliżsi, w tym zapewne także Genji. Wyraz urami, który funkcjonuje w tym wierszu jako kakekotoba (dosł. wyraz łączący) ${ }^{35}$, tworzy w ten sposób bezpośrednie powiązanie $\mathrm{z}$ toposem dymu (keburi). Wyraz ten wpisany w semantykę pozornie malowniczej scenerii, ukazującej pracę ludzi znad morza, przedstawia bowiem obraz, który

${ }^{35}$ Opiera się na zasadzie homofoniczności; korzysta z synonimii całkowitej lub częściowej (synonimem mogła być nawet tylko jedna sylaba w wyrazie) przenoszenie frazy w ramy nowej konstrukcji syntaktycznej i semantycznej; rodzaj gry słownej, gdzie wyrazy lub kilka sylab posiada podwójne znaczenie i funkcję. 
nabiera wyjątkowego znaczenia poprzez ewokowanie dymu „unoszącego się ponad Górą Toribe". Genji ma świadomość, że kiedy dotrze do Sumy i ujrzy dym unoszący się nad nadmorskimi warzelniami soli, będzie z żalem powracał do smutnych chwil towarzyszących ostatniemu pożegnaniu z żoną (Leduc 190-191). Tego typu skojarzenia potwierdzają z jednej strony, iż Genji wielokrotnie (?) uczestniczył w ceremoniach funeralnych odbywających się na Toribe, ale także to, że toponim Toribe funkcjonował $\mathrm{w}$ poezji jako jedno $\mathrm{z}$ wielu utamakura związanych z Kioto.

To właśnie atrybutywne konstrukcje zawierające utamakura Toribe nadawały słowu keburi jednoznaczny sens - dymu powstającego podczas spalania ludzkich zwłok. Nie było bowiem oczywistym, że widok dymu na brzegu morza musi koniecznie wywołać skojarzenia $\mathrm{z}$ tym konkretnym, powstającym w czasie kremacji. Zazwyczaj tak nie było, chociaż powyższy utwór mógłby tu stanowić jeden z wielu przykładów zaprzeczających takiemu stwierdzeniu. $W$ pierwszym rozdziale Genji monogatari - Kiritsubo (Paulownia) - możemy przeczytać: „Gdy minął czas [największej rozpaczy po śmierci damy Kiritsubo], zarządzono zwyczajowe ceremonie pogrzebowe. Jej matka, Kita no kata, ubolewała ze łzami w oczach, iż pragnęłaby umrzeć wraz z nią..." (Murasaki 1958: 23). W przywołanym fragmencie, w oryginalnym tekście japońskim, pojawia się wyrażenie keburi ni noboru, co dosłownie oznacza wznieść się [w powietrze] jak dym. Bardziej poetycki przekład powyższego zdania mógłby więc brzmieć: „,[...] ubolewała ze łzami w oczach, iż pragnęłaby - podobnie jak ona - wznieść się [ku niebu] jak dym...". Pominięcie (czy też niewspominanie) w tym zdaniu nazwy Toribe nie spowodowało zatarcia znaczenia keburi, rozumianego jako dym powstający podczas spopielania zwłok. Należy przy tym pamiętać, że w dawnych czasach keburi mogło oznaczać nie tylko dym czy mgiełkę, ale też sam proces kremacji, oraz - jak pokazuje między innymi cytowany fragment z Kiritsubo - metaforycznie śmierć (Matsumura et al. 433; Suzuki 427). Zatem w wierszu-odpowiedzi dla księżnej Ōmiyi wyraz Toribe pełni raczej funkcję ozdobnika, emfazy słowa keburi, które nie wpływa zasadniczo na odczytanie całego sensu utworu; sam kontekst, w jakim zostało użyte przez Genjiego słowo keburi, jednoznacznie nawiązuje do dymu kojarzącego się z przystołeczną „"nekropolią”.

\section{Pod dywanem z mchu}

Nawiązanie do toposu Toribe odnajdziemy również w interesującym cyklu wierszy, które wymieniali między sobą bohaterowie Sarashina nikki (Pamiętnik z Sarashiny, ok. 1060) autorstwa córki Sugawara no Takasuego (1008- po roku 1060). Jak wynika z tekstu, z powodu długiej choroby, a następnie śmierci starszej siostry autorki w 4 . roku Jian (1024 r., gdy ta miała 17 lat), wszyscy domownicy 
pogrążyli się w żałobie i wymieniali między sobą korespondencję, chcąc się wzajemnie pocieszyć. A oto fragment utworu:

Po kilku dniach jeden z moich krewnych przysłał mi opowieść zatytułowaną Kabane tazuneru Miya z następującą notatką: „Zmarła prosiła mnie kiedyś, abym wystarał się dla Niej o tę opowieść. Nie udało mi się odnaleźć jej wtedy, a teraz ktoś mi ją po prostu przysłał. Jakie to smutne!" Bardzo mnie te słowa wzruszyły, więc odpowiedziałam:

Po cóż pragnęła odnaleźć opowieść o pogrzebanych zwłokach

Ta której ciało pod mchami spoczywa?

[...]

Czy istnieje sposób, aby doznać pocieszenia?

Zginęty już nadmorskich ptaków stóp ślady.

Dlaczego także i je zmywa ten żałosny świat ptynacy?

Opiekunka przybyła odwiedzić grób, wracała zapłakana.

Ponoć wzniosła się ponad równiny"36

Dymu tam jednak także nie byto

Gdzie więc jest jakiś znak by odszukać grób, gdzie go ujrzałaś?

Słysząc to, moja macocha:

Nie napotkaliśmy żadnego znaku idąc odwiedzić grób

Lecz czy to nie tzy cisnace się do oczu maja być nam przewodnikiem?

36 Powyższy fragment wiersza jest rzadkim w literaturze dworskiej przykładem depersonifikacji (w ujęciu Artura Dobosza, który rozumie depersonifikację jako „przenośnię (metaforę) traktującą człowieka (osobę) jako obiekt niebędący człowiekiem (osobą)” (Dobosz 31). Autorka pisze o siostrze: „ponoć wziosła się ponad równiny" niczym dym kremacyjny, który został rozwiany nad nekropolią (,noborikemu nobe wa keburi mo nakarikemu"). Słowo nobe znaczy równina, ale również teren spopielania/chowania zwłok; ponadto fraza nobe no kemuri jest synonimem Toribe no kemuri (Matusmura et al. 919; Suzuki 1012). W wierszu zmarłej siostrze autorki została przypisana cecha nieludzka - lotność, właściwość charakteryzująca gazy, opary, dymy, chmury etc. Utwór mówi o nieboszce nie jako o człowieku, a o kębach dymu, w które ta się zamieniła i wzniosła w powietrze. Ślady depersonifikacji związanej z toposem kemuri odnajdziemy jednak także w innym fragmencie pamiętnika córki Takasuego:

„Kiedy przybyłam do stolicy, poproszono mnie, abym skopiowała rękopisy. W tym, który otrzymałam od Księżniczki, było napisane w następujący sposób:

Nastata noc, więc gdybym się nie ocknęta ze snu...

a dalej:

Jeśli ujrzysz w dali znikający dym w dolinie u podnóży Góry Toribe,

wiedz, że to ja.

Patrzyłam na te wspaniałe słowa, a łzy coraz bardziej cisnęły mi się do oczu.

W oryginale słowa kobiety brzmią: "Toribeyama tani no kemuri no moetataba, hakanaku mieshi ware to shirunamu" (Akisue 55). Jest to utwór, który autorka Sarashina nikki zapożyczyła z ostatniej księgi antologii cesarskiej Shūi[waka]shū (Zbiór poezji japońskiej pokłosia, 1006); por. Shui wakashū, http://jti.lib.virginia.edu/japanese/shuishu/index.html. Narratorka wiersza mówi o swojej nieludzkiej naturze, której fizyczną manifestacją będzie dym wznoszący się po jej śmierci nad Równiną Toribe. Stawia znak równości pomiędzy „ja” (ware) a „znikającym, kremacyjnym dymem” (kemuri). 
Osoba, która przysłała Kabane tazuneru Miya:

Znikty już i ślady stóp

wśród bambusowych traw na niezamieszkatych równinach

Wciąż płaczac, jakże musiałaś wędrować, aby je odnaleźć?

Mój brat, który owej nocy uczestniczył w ceremonii pogrzebowej, a widząc ten wiersz, odparł:

\section{Widziałem jak z płomieni dym powstat $i$ znikt}

Po cóż go szukać pośród bambusowych traw równiny?" (Akisue 81-85)

Mogłoby się wydawać, że to zbieg okoliczności, kiedy tuż po ceremoniach pogrzebowych rodzina zmarłej otrzymała od jakiegoś krewnego opowieść zatytułowaną Kabane tazuneru Miya (Księżniczka poszukująca zwłok; tekst zaginiony) z informacją, że nieboszczka prosiła o nią jeszcze za życia. Gest krewnego wzruszył autorkę, był jednak niezbyt fortunny, a wręcz cyniczny (Itō 50), gdyż na równinie Toribe dopiero co skremowano zwłoki jej siostry. Wiele bliskich zmarłej kobiecie osób odwiedzało jeszcze tamto miejsce, aby się z nią pożegnać, ale nie mogli odszukać jej grobu, podobnie jak tytułowa księżniczka z ofiarowanej opowieści. Oczywiście grobu odnaleźć nie mogli, gdyż on fizycznie nie istniał. Brat autorki i zmarłej wyraźnie mówi: „widziałem jak z płomieni dym powstał i znikł”, a inna osoba stwierdza ze smutkiem, że zmarła kobieta „wzniosła się ponad równiny”. Równiny Toribe, gdyż - choć toponim ten nie pojawia się w oryginale - to bez wątpienia jest tu mowa o tym konkretnym terenie (Morris 1975: 55). Implicytnie wskazuje na to wielokrotne występowanie słowa "równina”, która jest opisywana jako niezamieszkała i porośnięta bambusowymi trawami, oraz to, że poszukiwano na niej grobów, czy też - jak wynika z powyższego fragmentu - jakichkolwiek śladów po spopielonych zwłokach.

Warto zwrócić uwagę na jeszcze jeden wątek związany $\mathrm{z}$ analizowanym tu epizodem. Autorka pamiętnika, dziękując krewnemu za sprezentowaną opowieść, napisała: „Po cóż pragnęła odnaleźć opowieść o pogrzebanych zwłokach ta, której ciało pod mchami spoczywa?". W zdaniu tym, mającym oryginalnie formę pieśni waka37, kobieta użyła wyrażenia koke no shita (dosł. pod mchem/mchami), które tłumaczy się również jako 'pod ziemią', 'w grobie' (Matsumura et al. 452)38. Podobnie jak keburi ni noboru jest poetyckim określeniem palenia zwłok, tak fraza koke no shita funkcjonuje jako metonimia grobu. Najstarsze zabytki literatury dworskiej

${ }^{37}$ Waka jest tradycyjną poezją japońską, rozwijaną szczególnie na dworze, tworzoną od początków kultury japońskiej. Wyróżnia się wiele form poetyckich, m.in. tanka (pieśń krótka), chōka (pieśń długa), sedōka (pieśń z powtórzonym początkiem); Melanowicz 1994: 26-36, passim.

38 Innym wyrażeniem, które oznacza '[leżeć/spoczywać] w grobie', jest kusa(ba) no kage ('w cieniu traw'), semantycznie odpowiadające m.in. potocznemu, polskiemu frazeologizmowi '[wąchać] kwiatki od spodu' (Matsumura et al. 382). 
pokazują, że w takim właśnie znaczeniu pojawia się ona już w środkowym okresie Heian ${ }^{39}$. Część utworów - głównie kompozycji waka - wykorzystywała frazę koke no shita, łącząc ją z toposem Toribe. Ze względu na analogiczny kontekst sematyczny nawiązujący do śmierci i pochówku, motyw mchu był drugim - po motywie dymu - tematem tanatyczno-funeralnym zestawianym z nazwą przystołecznej nekropolii. Wykorzystał go również Fujiwara no Shigenori (1135-1187), poeta i wysokiej rangi dworzanin, który utraciwszy w 2. roku Eiman (1162) matkę wspomina o niej z tęsknotą $\mathrm{w}$ następującym wierszu:

\author{
Toribeyama \\ omoiyaru koso \\ kanashikere \\ hitori ya koke no \\ shita ni kuchinan \\ Rozmyślam \\ o Górze Toribe, \\ jest mi smutno, \\ gdyż ona tam samotnie \\ pod mchami marnieje ${ }^{40}$
}

Utwór ten został włączony do dziewiątej księgi antologii Senzai[waka]shū (Zbiór poezji tysiąclecia, 1187), która jest zatytułowana Aishō (Żałość). Wiele zamieszczonych w niej wierszy, podobnie jak ten autorstwa Shigenoriego, dotyczy smutku i tęsknoty po stracie bliskiej osoby. Poeta ubolewa nad zmarłą matką, którą - jak sugerowałaby ostatnia część wiersza - została pogrzebana na Górze Toribe. Fraza "marnieć pod mchami”, czyli de facto w grobie, brzmi tu dość jednoznacznie. Warto jednak rozważyć, czy możliwa jest jednak inna interpretacja ostatnich słów powyższego utworu?

Ówczesne obyczaje jasno stanowiły, że jedynie najwyższej rangi arystokracja i członkowie rodziny cesarskiej mogli liczyć na to, że po zakończeniu wszystkich obrządków pogrzebowych ich prochy zostaną zebrane do urny i będą pochowane $\mathrm{w}$ specjalnie przygotowanym ossuarium lub grobowcu rodowym (jap. bodaiji). Omówiono to szerzej na przykładzie ceremonii funeralnych matki cesarza Ichijō -

39 Jednym z najwcześniejszych przykładów, w których występuje fraza koke no shita, jest wiersz autorstwa Izumi Shikibu (?976-?), włączony m.in. do antologii Kin'yō[waka]shū (Zbiór złotych liści, 1124-1127). Utwór został skomponowany po tym, jak Izumi ujrzała na szatach swej zmarłej córki Koshikibu no Naishi jej wyhaftowane imię; jego treść brzmi następująco: „Morotomo ni koke no shita ni ha kuchizu shite uzumorenu na o miru zo kanashiki” ("Nie gryzę z nią ziemi pod mchami, a smucę się ujrzawszy jej niepogrzebane imię"); por. Takenishi 171.

40 Tekst oryginalny dostępny w bazie danych Jidai tōgō jōhō shisutemu, http://tois.nichibun.ac.jp/ database/html/waka/index_creation.html. 
Senshi, której szczątki ostatecznie trafiły do Kohaty41. Prochy pozostałe po kremacji zwłok dworzan niższych rang i zwykłych ludzi były pozostawiane na pastwę natury. Część popiołu rozwiewał wiatr, część łączyła się z ziemią, pozostając już w niej na zawsze. Użyźnioną glebę porastały następnie trawy i mchy, które stawały się miejscem pochówku kolejnych osób. Jeśli więc spojrzy się na frazę „marnieć pod mchami" właśnie z tej perspektywy, stwierdzenie, że matka Shigenoriego została pogrzebana, nie będzie się wydawało już takie oczywiste. Nie wnikając jednak w dalszą analizę, warto dla porównania przytoczyć jeszcze jeden przykład, który także wspomina o spoczynku pod mchami.

\author{
Toribeyama \\ kimi tazunu tomo \\ kuchihatete \\ koke no shita ni wa \\ kotaezaramashi \\ Poszukuję cię \\ na Górze Toribe, \\ lecz zczezłeś \\ pod mchami \\ i z pewnością mi nie odpowiesz...42
}

Autorem tego wiersza jest Ōe no Kinkage (daty życia nieznane) - poeta, stronnik cesarzy okresu Genpei (1180-1185) ${ }^{43}$ i przyjaciel Fujiwara no Teiki (1162-1241) ${ }^{44}$. Jak wynika z kotobagaki, wprowadzenia do wiersza, utwór Kinkage był odpowiedzią na pytanie, które przesłała mu pewna osoba. Używając czasownika kuchihatsu, czyli 'rozłożyć się/zgnić całkowicie', 'sczeznąć', autor daje adresatowi do zrozumienia, że po zmarłym nie ma już żadnego śladu. Nie ma możliwości, aby natknąć się na jego szczątki, a w konsekwencji również na jego fizyczny grób.

Trzecim motywem nawiązującym do tematyki przemijania w kontekście Toribe jest rosa, która z jednej strony jest metaforą łez, a z drugiej - czegoś łatwo ginącego lub zanikającego. I choć krople rosy są wielokrotnie przywoływane w kontekście innej, znanej nekropolii - Równiny Adashi - zachowało się kilka utworów, które mówią o rosie na Równinie Toribe. Jednym z takich utworów jest wiersz

${ }^{41}$ Podobne grobowce rodowe znajdowały się w Hino, Funaokayama, Kitashirakawa czy Sagano (Faure 237).

42 Tekst oryginalny dostępny w: Jidai tōgō jōhō shisutemu.

${ }^{43}$ Nazwa wzięła się od nazwisk dwóch wrogich sobie klanów: Minamoto (=Genji) i Taira (=Heike).

${ }^{44}$ Fujiwara no Teika (lub Sadaie) - arystokrata, pisarz i poeta, wybitny kaligraf i teoretyk literatury; autor m.in. Kindaishūka (Wybitne pieśni współczesne, 1209), Meigetsuki (Zapiski przy jasnym księżycu, 1235); redaktor Shinkokin [waka]shū (Nowy zbiór pieśni dawnych i dzisiejszych, 1205); por. Melanowicz 1994: 244-246. 
autorstwa wybitnego poety i podróżnika, Saigyō (1118-1190)45, który został skomponowany jesienią w 5. roku Bunji (1189 r.) podczas Zokusanjurokuban Miyagawa utaawase (Konkurs poezji nad rzeką Miya z trzydziestu sześciu rund [złożony] kontynuacja). Brzmi on następująco:

\author{
Naki hito o \\ kazouru aki no \\ yo mo sugarashi \\ oruru sode ya \\ Toribeno no tsuyu \\ Rozmyślam \\ w jesienne wieczory \\ o bliskich zmarłych, \\ a rękawy mych szat mokną \\ od rosy łez z Równiny Toribe \\ (Hagitani 2571)
}

W powyższym utworze nakładają się na siebie dwa obrazy. Pierwszy to śmierć, na którą bezpośrednio wskazuje fraza naki hito, zaś pośrednio - jako miejsce kremacji i grzebania zwłok - również toponim Toribeno. Drugi obraz wyraża smutek i nietrwałość, które symbolizuje tsuyu (rosa). Kontekst wiersza uwypukla więc wyraźnie problem przemijania. Taka wymowa była zamierzonym efektem, gdyż - w przeciwieństwie do spontanicznych kompozycji, nierzadko w odpowiedzi na wiadomość od innej osoby - w konkursie zorganizowanym nad brzegami Miyagawy jednym z tematów, który przypadł właśnie Saigyō, było mujō no kokoro (istota niestałości) (Hagitani 2587).

W samym wierszu autor korzysta $\mathrm{z}$ typowego dla poezji waka motywu wilgotnych rękawów szat, które od zawsze symbolizowały łzy głębokiego poruszenia czy smutku wywołanego rozstaniem (Matsumura et al. 691). Już pierwsze słowa mówią o emocjonalnym wzruszeniu, jakiego doświadcza podmiot liryczny spędzający długie, jesienne dni na rozmyślaniach o ludziach, którzy odeszli z tego świata. Łzy, które ociera on swymi rękawami, budzą żywe skojarzenia z rosą ${ }^{46}$, której lśniące krople zwisają na liściach i źdźbłach traw porastających Toribe. $\mathrm{W}$ ten sposób słowo tsuyu staje się łącznikiem dwóch przestrzeni - domowego zacisza, w którym wspominani są bliscy zmarli, gdzie jestem ja (podmiot liryczny), oraz Toribe, które ewokuje miejsce pochówku, gdzie „przebywają” oni. A dodatkowo, tęsknota i ból po stracie ukochanych osób - wyrażone symbolicznie poprzez rosę - przypominają, że „nikt na tym świecie nie może żyć wiecznie”.

\footnotetext{
45 Szerzej na temat twórczości Saigyō zob. Melanowicz 1994: 239-241.

${ }^{46} \mathrm{~W}$ poezji wykorzystywano też gotową metaforę sode no tsuyu (rosa na rękawach); por. Matsumura et al. 691 .
} 


\section{Podsumowanie}

Przedstawiony w niniejszym artykule opis i interpretacja znaczeń i metaforyki funeralnej Góry/Równiny Toribe jako jednego z miejsc nekropolicznych stanowi niezwykle interesujący materiał do rozważań nad treściami eschatologicznymi w średniowiecznej literaturze japońskiej. Właściwe zrozumienie istoty zagadnienia wymaga - jak wykazano - omówienia wielu aspektów religijno-filozoficznych, które wpłynęły na formę pochówków, stosunek człowieka do życia i śmierci, a w konsekwencji do zjawiska przemijania. Odzwierciedla je idea mujō, przypominająca ideę vanitas obecną przez wiele wieków w literaturze i kulturze europejskiej. Imaginarium i symbolika efemeryczności życia, związana zarówno z mujō, jak i vanitas, jest różna, jak odmienne jest tło kulturowo-religijne Europy i Japonii. Trupiej czaszce, pustym naczyniom czy zdmuchniętym świecom można przeciwstawić dym kremacyjny czy rosę na źdźbłach trawy. Istnieje jednak element wspólny, mianowicie przyroda, w której odwiecznie powtarza się cykl narodzin i śmierci. Zwiędłe kwiaty i ich opadłe płatki, motyl czy jętka, płynąca w rzece woda (niczym przesypujący się w klepsydrze piasek), podmuch wiatru i wiele innych - wszystkie te elementy przyrody cechuje niestałość i przemijanie. Japońska topika wanitatywna niemal $\mathrm{w}$ całości odwołuje się do zjawisk $\mathrm{z}$ otaczającego świata. Ta sama zasada odnosi się również do utworów o tematyce tanatyczno-funeralnej i nekropolicznej, które ewokują symbolikę ulotnego dymu czy nietrwałej rosy najbardziej sugestywnych wyrazów koncepcji mujō. Zwłaszcza "toribe-ński dym” stał się popularną frazą $\mathrm{w}$ literaturze dworskiej. W niniejszym artykule, skoncentrowanie uwagi na stricte toponimicznym ujęciu Toribe umożliwiło interpretację wybranych fragmentów literackich pod kątem jego rzeczywistego opisu. Z kolei szczegółowe zbadanie motywu Toribe jako toposu przybliżyło kilka możliwych ścieżek jego interpretacji - od rozbudowanej metafory, po jego funkcję zdobniczą. Autor wyraża nadzieję, że podjęta przez niego próba analizy utamakura Toribe pod względem znaczeń i funkcji w twórczości literackiej, głównie autorów literatury dworskiej, stanie się przyczynkiem do dalszych rozważań $w$ dyskursie nad tym rzadko podnoszonym zagadnieniem.

\section{BIBLIOGRAFIA}

A Tale of Flowering Fortunes. Przeł. William \& Helen Craig McCullough. Tom 1-2. Stanford: Stanford University Press, 1980.

Akatsuki, Kanenari et al., red. Karaku meishō zue. Higashiyama no bu. Tom 1. Kyōto, 1864.

Akisue, Ichirō. Sarashina nikki seishaku. Tōkyō: Chūdōkan, 2000.

Akutagawa, Ryūnosuke. Życie szaleńca. Red. M. Melanowicz. Warszawa: Wydawnictwo Akademickie Dialog, 1998.

Biblia Tysiąclecia. Pismo Święte Starego i Nowego Testamentu. Wyd. V. Poznań: Pallottinum, 2007. 
Conder, Josiah. Kwiaty Japonii i sztuka kompozycji kwiatowych. Przekł. I. Kania. Kraków: Universitas, 2002.

Dobosz, Artur. „Metamorfoza - metafora - antropomorfizacja - deantropomorfizacja”. Filo-Sofija 2010, nr 10.

Eiga monogatari. Tom 1. Tōkyō: Iwanami Shoten, 1975.

Faure, Bernard. The power of denial: Buddhism, purity, and gender. Princeton: Princeton University Press, 2003.

Fujimura, Saku, Nishio Makoto, red. Nihon bungakushi jiten. Tōkyō: Nihon Hyōron Shinsha, 1960.

Hagitani, Boku. Heianchō utaawase taisei. Tom 8. Tōkyō: Sekiteikyo Shikaban, 1959.

Hall, John W. Japonia. Od czasów najdawniejszych do dzisiaj. Przeł. K. Czyżewska-Madajewicz. Warszawa: Państwowy Instytut Wydawniczy, 1979.

Hall, John W., Mass, Jeffrey P., red. Medieval Japan. Essays in institutional history. Stanford: Stanford University Press, 1988.

Heike monogatari. Tom 1. Seria "Nihon koten bungaku taikei” 32. Red. I. Takagi et al. Tōkyō: Iwanami Shoten, 1959.

Hosaka, Hiroshi. Tsurezuregusa. Tōkyō: Gakutōsha, 1951.

Huey, Robert N. „The medievalization of poetic practice”. Harvard Journal of Asiatic Studies 50 (1990). S. 651-668.

Inada, Natsuko. "Nihon kodai sōsōgirei no tokushitsu: sōsōryō kara mita tennō to uji”. Shigaku zasshi 109 (2000). S. 1607-1640.

Itō, Moriyuki. „Takasue no musume to monogatari: ane, mamahaha to no kankei o chūshin ni”. Hirosaki daigaku kokugo kokubungaku 15 (1993). S. 33-53.

Izumi, Shikibu. Izumi Shikibu nikki. Seria „Nihon koten bungaku taikei” 20. Red. T. Suzuki et al. Tōkyō: Iwanami Shoten, 1957.

Jidai tōgō jōhō shisutemu. Web. 02.09.2014 <http://tois.nichibun.ac.jp/ database/html/waka/index_ creation.html>

Kamo no, Chōmei. Hōjōki. Zapiski z pustelni. Przeł. Krystyna Okazaki. Estetyka japońska. Antologia. Red. K. Wilkoszewska. Tom 1. Kraków: Universitas, 2001.

Keene, Donald. Uczuciowość kobieca w okresie Heian. Przekł. Wioletta Laskowska. Estetyka japońska. Antologia. Red. K. Wilkoszewska. Tom 2. Kraków: Universitas, 2005.

Kotański, Wiesław. Dziesięć tysięcy liści. Antologia literatury japońskiej. Warszawa: Państwowe Wydawnictwo Naukowe, 1961a.

Kotański, Wiesław. „Kilka uwag o środkach zdobniczych w starożytnej poezji japońskiej”. Przegląd Orientalistyczny 38 (1961b). S. 129-140.

Leduc, Jeannette Marie. Concealment and revelation in the two worlds on "Genji monogatari". An analysis and translation of the "Hanachirusato" chapter and the introductory portion of the "Suma" chapter. Vancouver: The University of British Columbia, 1981.

Libera, Zdzisław, Pietrusiewicz, Jadwiga, Rytel, Jadwiga. Literatura polska. Od średniowiecza do odrodzenia. Warszawa: Państwowe Wydawnictwo Naukowe, 1989.

Matsumura, Akira, Imaizumi, Tadayoshi, Shuzui, Kenji. Ōbunsha kogo jiten. Tōkyō: Ōbunsha, 1981.

McGreal, Ian P. Wielcy myśliciele Wschodu. Przeł. Zofia Łomnicka, Irena Kałużyńska. Warszawa: Wydawnictwo al fine, 1997.

Melanowicz, Mikołaj. Literatura japońska. Od VI do połowy XIX wieku. Tom 1. Warszawa, Wydawnictwo Naukowe PWN, 1994.

Melanowicz, Mikołaj. Historia literatury japońskiej. Warszawa: Wydawnictwo Naukowe PWN, 2011.

Mizukaki, Hisashi. Meisho utamakura ichiran. 2006. Web. 28.03. 2012. <http://www.asahi-net.or.jp/ $\sim$ sg2h-ymst/yamatouta/utamaku.html> 
Morita, Koji. „Symbolika 'sakury' w „Genji monogatari” i jej reinterpretacja”. Dziesięć wieków „Genji monogatari" w kulturze Japonii. Red. Iwona Kordzińska-Nawrocka. Warszawa: Wydawnictwa Uniwersytetu Warszawskiego, 2009.

Morris, Ivan. Świat Księcia Promienistego. Przeł. Tadeusz Szafar. Warszawa: Państwowy Instytut Wydawniczy, 1973.

Morris, Ivan. As I Crossed a Bridge of Dreams. London: Penguin Books, 1975.

Murasaki, Shikibu. Genji monogatari. Seria "Nihon koten bungaku taikei” 14. Red. T. Yamagishi. Tōkyō: Iwanami Shoten, 1958.

Murasaki, Shikibu. Genji monogatari. Seria „Nihon koten bungaku taikei” 15. Red. T. Yamagishi. Tōkyō: Iwanami Shoten, 1959.

Murasaki, Shikibu. Genji monogatari. Seria "Nihon koten bungaku taikei” 18. Red. T. Yamagishi. Tōkyō: Iwanami Shoten, 1963.

Murasaki, Shikibu. Genji monogatari. Tom 5. Red. A. Abe, K. Akiyama, G. Imai. Tōkyō: Shōgakkan, 1972.

Nishiyama, Mika. „Kusōzu no tenkai - Ono no Komachi to Danrin kōgō no «shi no monogatari»”. Kokubungaku: kaishaku to kanshō 73 (2008). S. 120-127.

Olszewski, Krzysztof. „Kolor kwiatów drzewa śāla przypomina, że wszystko co rozkwita, niechybnie szczeźnie - o wpływie nauki buddyjskiej o niestałości wszechrzeczy (mujōkan) na estetykę japońską okresu Heian (IX-XII w.)". Estetyka transkulturowa. Red. K. Wilkoszewska. Kraków: Universitas, 2004.

Ōno, Susumu, Satake, Akihiro, Maeda, Kingorō. Iwanami kogo jiten. Wyd. VII. Tōkyō: Iwanami Shoten, 1980.

Shintani, Takanori. 'Osōshiki' no Nihonshi. Tōkyō: Seishun Shuppansha, 2003.

Shui wakashū. 2000. Japanese Text Initiative. University of Virginia Library, Web. 13.01.2015 <http://jti.lib. virginia.edu/japanese/shuishu/index.html>

Suzuki, Kazuo. Zen'yaku kihon kogo jiten. Wyd. III. Tōkyō: Sanseidō, 2007.

Szajowska, Magdalena. „Obrzędy przejścia”. W kręgu tradycji dworu Heian. Red. I. Kordzińska-Nawrocka. Warszawa: Wydawnictwo Trio, 2008.

Takenishi, Hiroko. Izumi Shikibu, w: Jinbutsu nihon no joseishi, t. 1, Karei naru kyūtei saijo. Red. Enchi Fumiko, Shūeisha, Tōkyō 1977.

Varley, Paul. Kultura japońska. Przeł. Magdalena Komorowska. Kraków: Wydawnictwo Uniwersytetu Jagiellońskiego, 2006.

Watanabe, Kikuma, Funo, Shūji. „'Toribeno' (Kyōto Amidagamine sanro) no kūkanteki tokushitsu ni kansuru kōsatsu". Nihon kenchikugakkai keikakukei ronbunshū 543 (2001). S. 187-194. 